Paediatrica Indonesiana 14 : 185 - 188. Nov. - Dec. 1974.

From the Department of Child Health, Medical School

University of Indonesia, Jakarta

\title{
Policies and Practices Recommended in Feeding \\ Older Infants (more than 6 months and under 1 year) and Young Children (1 to 2 years) in Indonesia *
}

by

\section{R. SUTEDJO}

In general breast milk production starts biologically to decrease by the infant's age of approximately 5 months, so that supplementary feeding becomes necessary by that age. In fact, at the age of 2 months supplementation can already be started once or twice daily in the form of a biscuit $(20 \mathrm{gm})$ soaked in milk or tea or in the form of fruits either banana $(50 \mathrm{gm})$, papaya $(50 \mathrm{gm})$ or orange juice $(50 \mathrm{gm})$.

This supplement provides approximately $3 \mathrm{gm}$ of protein, 150 Calories and small amounts of vitamins $\mathbf{A}$, $\mathrm{B}_{1}$ and $\mathrm{C}$.

Next to those additional proteins, calories and vitamins, although small in amounts, the benefit of this early supplementation is that the infant starts already to be trained in eating. Biscuit or fruits are given at 11 o'clock in the morning.
By the age of 4-5 months one time breast feeding at 9 o'clock is discarded and replaced by the first solid food, i.e. a porridge consistnig of 150 $\mathrm{ml}$ cow's milk, $10 \mathrm{gm}$ rice flour and $10 \mathrm{gm}$, of cane sugar.

This cooked porridge contain $5 \mathrm{gm}$ protein $(86 \%$ animal and $14 \%$ vegetable), $210 \mathrm{IU}$ vitamin $\mathrm{A}$, vit $\mathrm{B}_{1}$ and $C$ but also minerals in the form of $136 \mathrm{mg} \mathrm{Ca}, 64 \mathrm{mg}$ phosphorus and $0.3 \mathrm{mg}$ iron and provides approximately 165 calories.

The time schedule at this age becomes as follows:
6 o'clock
breast feeding
9
milk - flour - sugar
porridge
11 biscuit or fruits
1 breast feeding
4 breast feeding
7 breast feeding
10 breast feeding

* Invited Paper Seminar - Protein Calorie Advisory Group United Nations, Singapore, $25-26-27$ November 1974. 
Eventually, a second biscuit or fruits can be added at 5-6 o'clock in the afternoon if required by the infant.

Instead of rice, other kinds of flour can be used e.g. soyabean, quaker oats, corn flour as to make the flavour every day different so that the infant does not get bored.

At the age of 5 to 6 months another breast feeding, preferably of the 7 o'clock in the evening, can be discarded and replaced by a solid food which at this time is more complex than the first one.

It is made of $50 \mathrm{gm}$ rice grain, vegetables in the form of either $10 \mathrm{gm}$ spinach, $10 \mathrm{gm}$ tomato or $20 \mathrm{gm}$ of carrots. Animal proteins are added in the form of either one egg, chicken liver, finely sliced meat, chicken, or fish. Vegetable proteins of high quality, e.g. soya bean ourd ("tahu or "taufu") or fermented bean cake ("tempeh") can also be used.

Once again variation of the ingredients is necessary as to make the infant not loose his appetite.

Additional ketchup, bouillon or other kinds of sauce can be added to make the whole dish as palatable as possible. Such a dish is called "nasi tim" (nasi $=$ cooked rice, tim $=$ soft prepared). As a matter of fact, the proper way of preparation is "au bain marie". It should be sieved prior to be given by spoon to the infant.

It contains approximately $8 \mathrm{gm}$ of protein, 150 calories, $8960 \mathrm{IU}$ vit. A, small but sufficient amounts of vi$\operatorname{tamin} \mathrm{B}_{1}$ and $\mathrm{C}$, and $57 \mathrm{mg}$ Calcium, $165 \mathrm{mg}$ phosporus and $3.7 \mathrm{mg}$ of iron as minerals.

At the age of 6-7 months another second "nasi tim" replaces the I o'clock breast feeding, so that the regimen becomes as follows:

$\begin{aligned} 6 \text { o'clock } & \text { breast } \\ 9 & \text { porridge } \\ 11 & \text { fruits or biscuit } \\ 1 & \text { nasi tim } \\ 4 & \text { breast } \\ 7 & \text { nasi tim } \\ 10 & \text { breast }\end{aligned}$

This regimen remains until the infant reaches the age of 9-10 months, i.e. the time of total weaning. At this age the "nasi tim" needs not to be sieved any more. Properly soft cooked rice is usually tolerated.

Total weaning is then started. Weaning actually starts already step by step from the age of 5-6 months when 6 times breast feeding are reduced gradually to only 3 times.

At the age of 10 months the first breast feeding to be discarded and replaced by milk $(150 \mathrm{ml})$ is that of 4 o'clock in the afternoon, follow. ed subsequently by the early morning and finally by the last night breast feeding.

In doing so it is expected that weaning procedure can be smoothly carried out and unnoticed by the infant. 
Imported instant solid infant foods preppared on the western way are available in the Indonesian market, However, substitutes of the "nasi tim" are not acceptable to the Indonesian infant. On the contrary, substitute of the 9 o'clock porridge is very much liked by infants of poor as well as rich people.

Locally made porridge as a dry powder in tins named SNM ( $\mathbf{S}=$ susu or skim milk, $\mathrm{N}=$ nasi or rice flour, $\mathrm{M}=$ minyak or a combination of a spray dried coconut and peanut oil) is also available against much lower price and is also acceptable to the Indonesian infant.

Locally made substitutes of "nasi tim" are however not yet available. If the parents can afford to buy milk and provide the infant with properly prepared solid foods, total weaning at the age of 10 months will not give any hazard.

If by occasion production of breastmilk is still adequate enough at the infant's age of 10 months, prolonged breast feeding ean certainly be advised. The role of the breastmillk must then be a supplementary one. This policy should actually be adopted from the moment when 3 times solid food are already introduced, i.e. from the age of 6-7 months on.

We are not of the opinion to encourage breast feeding as long as possible for the following reasons. In general the amount of the breast milk gradually decreases with the age of the child and the ignorant mother might think that her sole breast milk is sufficient enough to rear her child.

The above mentioned regimen could be maintained tilli the child reaches the age of 1 year and over with the understanding that the first solid food could then be considered as breakfast and could be varied with cake made of peanuts, soya beans or other legumes, bread, toast etc. The first and second "nasi tim" will then become the lunch and dinner respectively of which the soft cooked rice might be replaced by plain rice as consumed by the rest of the members of the family. In fact the child starts to share the menu of the family with the exception of hot dishes.

As mentioned before, breakfast could be made variable, but in most families it consists of cooked rice plus vegetable soup with a piece of meat, fish, egg, liver or soya bean cake.

Even the family lunch and dinner consist of the same ingredients. However, it is up to the mother to change the flavour every day and for every occasion.

After lunch or dinner usually a dessert is served in the form of fruits of the season providing additional calories and vitamins,

The richer the family the more amount and varieties of proteins are served on the table. 
For the child the milk could be continued as a drink. The times to be given are not necessarily strict and fixed. Half a liter per day given bit by bit in between the meals is suffieient. It is certainly undeniable that half a liter of milk per day adds considerable amount of complete proteins to the menu of the child in order to obtain optimal growth provided that the parents could afford to buy every day half a liter milk for a length of period.

The questition remains still unsolved whether supplementary milk should be strongly advised to children of older than 1 year especially in deve- loping countries where the buying power is minimal and where milk drinking is unfamiliar since centuries..

It is however undeniable that non milk drinking nations exist which are able to achieve socio-economical, technological and health progress as equal as mill drinking nations.

It is therefore suggested that in developing countries priority should be given to intensification of production of fish, meat, poultry, legumes as to meet the need of proteins for the population which I think can never be entirely met by milk and it's products. 